ISSN 1678-3921

Journal homepage: www.embrapa.br/pab

For manuscript submission and journal contents, access: www.scielo.br/pab

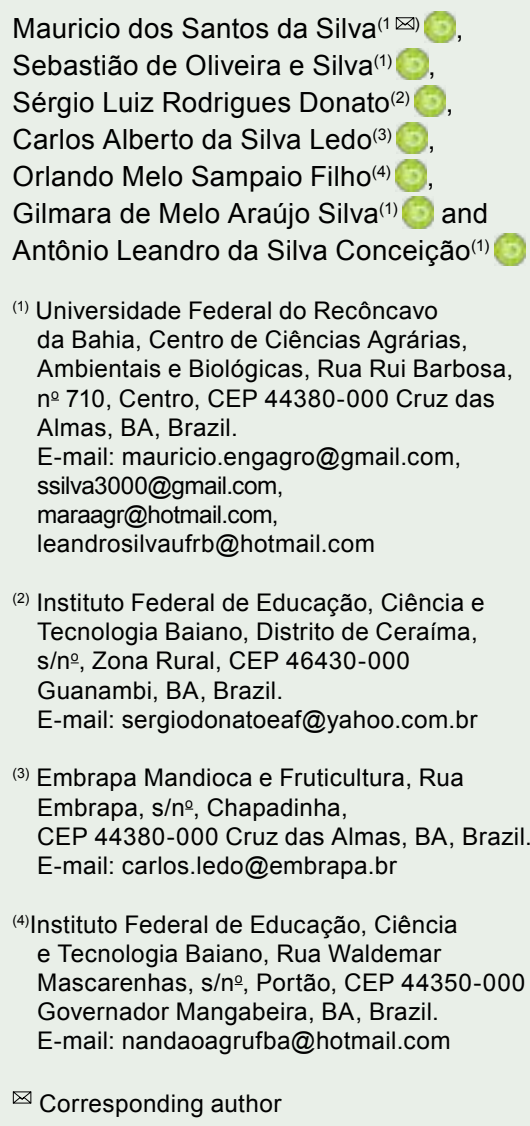

Received

May 7, 2018

Accepted

June 7, 2019

How to cite

SILVA, M. dos S. da; SILVA, S. de O. e; DONATO, S.L.R.; LEDO, C.A. da S.; SAMPAIO FILHO, O.M.; SILVA, G. de M.A.; CONCEIÇÃO, A.L. da S. Optimal experimental plot size for papaya cultivation. Pesquisa Agropecuária Brasileira, v.54, e00768, 2019. DOI: https://doi.org/10.1590/S1678-3921. pab2019.v54.00768.

\section{Optimal experimental plot size for papaya cultivation}

\begin{abstract}
The objective of this work was to determine the optimal size of experimental plots for the evaluation of agronomic characteristics and fruit quality of papaya, by the linear model of plateau response, under soil and climatic conditions of the Recôncavo Baiano region, in the state of Bahia, Brazil. The experiment consisted of a uniformity test, with the papaya lineage L78, at $3 \times 2$ m spacing, in 16 rows with 22 plants, totaling 352 plants and $2,112 \mathrm{~m}^{2}$ useful area. Each plant was considered as a basic unit, and 11 forms of pre-established plots, with rectangular and row formats, were obtained. The agronomic characteristics and fruit quality were evaluated in the plots. Optimal plot size varied greatly among the variables related to agronomic characteristics, with a greater participation of the variable number of marketable fruit per plant at 14 months (16 basic units). The optimal plot size for the evaluation of the agronomic characteristics and fruit quality in papaya is eight experimental units, with $48 \mathrm{~m}^{2}$ area, at a spacing of $3 \mathrm{~m}$ between rows and $2 \mathrm{~m}$ between papaya plants.
\end{abstract}

Index terms: Carica papaya, experimental accuracy, uniformity.

\section{Tamanho ótimo de parcelas experimentais para o cultivo de mamoeiro}

Resumo - O objetivo deste trabalho foi determinar o tamanho ótimo de parcela experimental para avaliação de características agronômicas e qualidade de fruto de mamoeiro, por meio do modelo linear de resposta platô, nas condições edafoclimáticas do Recôncavo Baiano, no Estado da Bahia. O experimento consistiu de um teste de uniformidade, com a linhagem de mamoeiro L78, no espaçamento $3 \times 2 \mathrm{~m}$, em 16 fileiras com 22 plantas, com o total de 352 plantas e área útil de $2.112 \mathrm{~m}^{2}$. Cada planta foi considerada como unidade básica, tendose obtido 11 formas de parcelas pré-estabelecidas, com formatos retangulares e em fileiras. As características agronômicas e a qualidade dos frutos foram avaliadas nas parcelas. O tamanho ótimo de parcela variou muito entre as variáveis relativas às características agronômicas, com maior participação da variável número de frutos comerciais aos 14 meses (16 unidades básicas). $\mathrm{O}$ tamanho ótimo de parcela para avaliação das características agronômicas e da qualidade do fruto em mamoeiro é de oito unidades experimentais, com área de $48 \mathrm{~m}^{2}$ no espaçamento de $3 \mathrm{~m}$ entre fileiras e $2 \mathrm{~m}$ entre plantas de mamoeiro.

Termos para indexação: Carica papaya, precisão experimental, uniformidade.

\section{Introduction}

The Caricaceae family has a great economic importance in the production of commercial fruits, in which Carica papaya L. stands 
out in the Brazilian agribusiness. In 2017, Brazil exported approximately US $\$ 41.35$ million of papaya, mainly to the European market (Anuário Brasileiro da Fruticultura, 2018). The Northeastern of Brazil accounts for $59.45 \%$ of the national papaya production, for which the state of Bahia contributes with $34.89 \%$, followed by the states of Espírito Santo (29.43\%) and Ceará (10.93\%) (IBGE, 2017).

In the search for a better performance of papaya cultivations, researchers have pointed out the need of experiments for the genetic improvement, and the launching of new cultivars with desirable agronomic characteristics that meet the demands of the domestic and foreign markets (Oliveira et al., 2010; Dantas et al., 2015; Luz et al., 2015). Thus, important aspects related to experimental planning should be considered, in order to obtain reliable research results, such as the optimal size of the plot to be adopted (Cargnelutti Filho et al., 2015).

The determination of the plot size is a relevant matter to use of the experimental design, since its optimal definition attaches a greater precision to the research. Indeed, an optimal size and shape allows of the detection of significant differences between treatments and the reduction of experimental errors (Donato et al., 2008).

The estimation of the optimal plot size is one of the ways to increase the experimental accuracy, and to maximize the information obtained, which gives the opportunity to the researcher to maximize the resource utilization, as well as to gain a greater control and improve the management of the experimental area (Silva et al., 2012). In this sense, the linear model of plateau response (LMPR) has been used to determine the optimum plot size of different crops, as follows: maize hybrids (Cargnelutti Filho et al., 2011), in vitro conservation of passion fruit (Peixoto et al., 2011), pineapple (Silva et al., 2012), pineapple (Leonardo et al., 2014), and sunflower (Sousa et al., 2015).

The linear model of plateau response consists of two segments, in which the first one describes a descending, or ascending, line up to the point that determines the plateau. After this point, the vector assumes a constant value, determining the second segment, in which the dependent variable represents the value of the coefficient of variation, and the independent variable assumes the size values of the plots (Paranaiba et al., 2009).
However, even when working with a single species, the size of the plot may vary according to the soil characteristics, genetic material used, evaluated variables, resources and management adopted in the experiment, and the method applied in the estimation (Donato et al., 2008; Sousa et al., 2015).

The objective of this work was to determine the optimal size of the experimental plot for the evaluation of the agronomic characteristics and fruit quality of papaya, by the linear model of plateau response, under soil and climatic conditions of the Recôncavo Baiano.

\section{Materials and Methods}

The experiment was carried out between August 2015 and March 2017, at the experimental area of Embrapa Mandioca e Fruticultura, in the municipality of Cruz das Almas (12\%40'31.62" S, 395'24.04"W, at $220 \mathrm{~m}$ altitude), in the state of Bahia, Brazil. The climate is an Af type, that is, a warm climate, according to the classification of Köppen, with the coldest month, with temperature above $18^{\circ} \mathrm{C}$, and the driest month with precipitation equal to, or greater than $60 \mathrm{~mm}$; the mean annual temperature is $24.5^{\circ} \mathrm{C}$, the relative humidity is $82 \%$, and the mean annual rainfall is 1,200 $\mathrm{mm}$ (Embrapa, 1993).

The soil is classified as a cohesive yellow Alic Latosol, with a clayey texture and 0 to $3 \%$ slope, before the experimental area was cultivated with banana. The chemical characterization of the soil had characteristics described as follows. At $0-20 \mathrm{~cm}$ soil depths: $32 \mathrm{~g} \mathrm{~kg}^{-1}$ organic matter; $\mathrm{pH}\left(\mathrm{H}_{2} \mathrm{O}\right) 6.4 ; 13 \mathrm{mg} \mathrm{dm}^{-3} \mathrm{P} ; 0.41$, 2.24, 1.28, and $1.68 \mathrm{cmol}_{\mathrm{c}} \mathrm{dm}^{-3} \mathrm{~K}, \mathrm{Ca}, \mathrm{Mg}$, and $\mathrm{H}+\mathrm{Al}$, respectively; $5.66 \mathrm{cmol}_{\mathrm{c}} \mathrm{dm}^{-3}$ effective cation exchange capacity; and $70 \%$ base saturation (BS). At $20-40 \mathrm{~cm}$ soil depths, $17 \mathrm{~g} \mathrm{~kg}^{-1}$ organic matter; $\mathrm{pH}\left(\mathrm{H}_{2} \mathrm{O}\right) 6.0$; $14 \mathrm{mg} \mathrm{dm}^{-3} \mathrm{P} ; 0.41,2.06,0.94$, and $2.44 \mathrm{cmol}_{\mathrm{c}} \mathrm{dm}^{-3} \mathrm{~K}, \mathrm{Ca}$, $\mathrm{Mg}$, and $\mathrm{H}+\mathrm{Al}$, respectively; $5.66 \mathrm{cmol}_{\mathrm{c}} \mathrm{dm}^{-3}$ effective cation exchange capacity; and $59 \%$ base saturation (BS). After the soil analysis has been performed, the correction and fertilization was proposed according to Oliveira \& Coelho (2009).

Papaya seed of the L78 lineage were obtained from the Papaya Active Germplasm Bank maintained by Embrapa. Three seed were sown in plastic bags filled with soil. Thinning was done at 15 days after plant emergence, in order to maintain one plant per plastic bag. After 40 days, plants were transplanted 
to the experimental area, with six plants per hole. In the beginning of flowering, another thinning was performed to keep only one plant showing hermaphrodite inflorescences.

A completely randomized design was used and a uniformity test was carried out. The area was formed by 18 rows of 24 plants each, at $3 \times 2 \mathrm{~m}$ spacing, in which the 16 central rows with 22 plants was considered useful, totaling 352 plants and floor area of 2,112 $\mathrm{m}^{2}$. Evaluations considered each plant as a basic unit (bu) in $6 \mathrm{~m}^{2}$, thus making 352 basic units defined from the blank assay map, whose combinations generated 11 types of plots with different shapes and relative contributions.

Papaya agronomic characteristics and fruit quality were evaluated for the following variables: plant height (m) at six, 12, and 18 months; distance (m) from the ground surface to the insertion point of the newest leaf located in the stem apex at six, 12, and 18 months after planting; insertion height of the first fruit (m) measured from the ground surface and the insertion point of the first functional flower (able to produce fruit), at the start of fruit production; stem diameter (cm) at six, 12, and 18 months after planting, measured at $20 \mathrm{~cm}$ above the soil surface; precocity, measured in days, considering the date of planting and the first harvest of fruit; number of marketable fruit per plant at 14 months after planting; productivity $\left(\mathrm{Mg} \mathrm{ha}^{-1}\right)$, by multiplying the number of marketable fruit per plant by the average weight of fruit per plant, considering $3 \mathrm{x}$ $2 \mathrm{~m}$ spacing; fruit length, with a pachymeter from the fruit base to the apex; fruit diameter $(\mathrm{cm})$ at the thickest part of the fruit, using a pachymeter; fruit weight (g), consisting of the weight of fruit harvested at maturity stage ( $1 / 4$ mature, having up to $25 \%$ of yellow bark) per plant, on an analytical balance. Fruit firmness $\left(\mathrm{kg} \mathrm{cm}^{-2}\right)$ determined, with a penetrometer, from three readings taken at the central region of intact mature fruit; pulp thickness (cm), expressing the thickness of the largest pulp, after the cross-section of fruit, and measured with a pachymeter; diameter of the internal cavity of fruit $(\mathrm{cm})$, measured at the central part of fruit. In case of cavities of a star shape, measurements were taken from one end to another, after selecting the ends at the greatest distance; soluble solids ( ${ }^{\circ}$ Brix), obtained with a portable analog refractometer, model Brix Tester (Reichert Technologies). For the determination of the optimal plot size, the linear model of plateau response (LMPR) was used (Paranaiba et al., 2009) by the equation

$$
C V i= \begin{cases}\beta_{0}+\beta_{1} X+\varepsilon_{i} & \text { if } X \leq X_{0} \\ P+\varepsilon_{i} & \text { if } X>X_{0}\end{cases}
$$

in which: $\mathrm{CVi}$ corresponds to the coefficient of variation (\%) observed in the experiment; $\mathrm{X}$ is the size of the plot in basic units; $\mathrm{X}_{0}$ is the optimal plot size, represented by the point of intercession for a plateau, relatively to the abscissa; $\mathrm{P}$ is the coefficient of variation at the point corresponding to the plateau; $\beta_{0}$ and $\beta_{1}$ are the intercept and angular coefficients of the linear segment, respectively; $\varepsilon$ is the error, associated with the $\mathrm{CVi}$, considered normally and independently distributed with mean 0 and constant variance $\alpha_{\varepsilon}^{2}$.

The estimated value of is the optimal plot size (in basic units) that would be recommended for this type of experiment. Thus, the optimal plot size was estimated by the expression $X_{0}=\left(\widehat{P}-\widehat{\beta}_{0}\right) / \widehat{\beta}_{1}$, in which: $\widehat{\beta}_{0}, \widehat{\beta}_{1}$, and $\widehat{P}$ represent the estimate values of the equation parameters.

The values of the coefficients of variation (CV), variance, and other necessary determinations were calculated using Microsoft Excel. Equations and model graphs were obtained with the help of the SAEG software (Ribeiro Júnior, 2001), with the dependent variable $(\mathrm{CV})$ and the independent variable, and plot size, in the basic unit for each variable.

\section{Results and Discussion}

The coefficients of variation ranged from 0.48 to $55.81 \%$ for fruit length and number of marketable fruit per plant in nine months, respectively (Tables 1 and 2).

The values of the coefficients of variation generally show a decrease when the value of the plot size increases, however, it is not linear (Tables 1 and 2). This way, parcels with a larger dimension in the perpendicular direction to plant rows, irrespectively of the format, express, in general, smaller coefficients of variation, admitting that the plot shape directly influences the experimental precision. Donato et al. (2008) and Santos et al. (2016) calculated the plot size in banana and broccoli, respectively, and observed reductions of the coefficients of variation, with different rates of reduction, and increase of the plot. 
The parameters $\beta_{0}$ and $\beta_{1}$ and $\mathrm{CV}(\%)$ showed different values for the characteristics evaluated (Tables 3 and 4). By the LMPR, the optimal plot size is determined at the abscissa of the straight line generated by the linear model, in conjunction with the regression plateau, using the model proposed in the evaluation of rice, sunflower, and pineapple cultivation according to Paranaiba et al. (2009), Leonardo et al. (2014), and Sousa et al. (2015), respectively.

The estimates of the optimal plot size $\left(\mathrm{X}_{0}\right)$ for morphoagronomic characters and fruit quality ranged from $5.14 \mathrm{bu}$, for fruit weight, to $\mathrm{X}_{0}=15.09 \mathrm{bu}$ for the number of market fruit by plant at 14 months, corresponding to $\mathrm{X}_{0}=7.90 \mathrm{bu}$ general average, approximately $8 \mathrm{bu}$, resulting in $48 \mathrm{~m}^{2}$ area (Tables 3 and 4). This result differs from that found by Schmildt et al. (2016), who carried out a field experiment with papaya, using the method of maximum modified curvature and maximum curvature of the coefficient of variation, and concluded that the optimal plot size is six plants. However, this divergence is justified by the differences between the methods used, since the modified maximum curvature method tends to estimate smaller plot sizes than other methods (Donato

Table 1. Estimates of coefficient of variation (CV), depending on the plot size in basic unit (Xbu), for agronomic characteristics of Carica papaya plants.

\begin{tabular}{|c|c|c|c|c|c|c|c|c|c|c|c|c|c|}
\hline \multirow[t]{2}{*}{ Form } & \multirow{2}{*}{$\begin{array}{c}\text { Dimension } \\
\mathrm{F} \times \mathrm{P} / \mathrm{F}\end{array}$} & \multirow[t]{2}{*}{ Xbu } & \multicolumn{11}{|c|}{ Coefficient of variation (\%) } \\
\hline & & & PH6 & PH12 & PH18 & IHFF & SD6 & SD12 & SD18 & PREC & NMF9 & NMF14 & PROD \\
\hline Plant & $1 \times 1$ & 1 & 16.06 & 12.37 & 10.33 & 15.21 & 29.49 & 14.21 & 11.73 & 11.22 & 55.81 & 38.14 & 39.89 \\
\hline Row & $2 \times 1$ & 2 & 12.52 & 9.80 & 8.26 & 10.77 & 22.92 & 11.51 & 9.53 & 7.48 & 44.40 & 29.42 & 32.58 \\
\hline Row & $4 \times 1$ & 4 & 9.88 & 7.64 & 6.70 & 8.20 & 17.57 & 9.33 & 7.98 & 5.66 & 36.97 & 24.85 & 28.64 \\
\hline Row & $8 \times 1$ & 8 & 7.14 & 5.04 & 4.92 & 6.06 & 12.22 & 7.44 & 6.47 & 4.36 & 25.74 & 19.53 & 21.39 \\
\hline Row & $1 \times 11$ & 11 & 8.01 & 7.34 & 6.34 & 6.15 & 12.38 & 8.40 & 7.34 & 3.97 & 30.68 & 26.80 & 25.79 \\
\hline Row & $16 \times 1$ & 16 & 5.62 & 4.09 & 2.68 & 4.72 & 8.58 & 4.31 & 3.45 & 3.40 & 16.69 & 13.61 & 14.20 \\
\hline Rectangular & $2 \times 11$ & 22 & 7.31 & 6.16 & 5.54 & 4.27 & 11.24 & 7.77 & 6.72 & 3.37 & 27.86 & 21.28 & 22.71 \\
\hline Rectangular & $16 \times 2$ & 32 & 4.44 & 3.74 & 2.21 & 3.69 & 7.04 & 3.83 & 2.75 & 3.02 & 15.48 & 12.72 & 13.67 \\
\hline Rectangular & $2 \times 22$ & 44 & 4.88 & 4.56 & 4.81 & 3.10 & 7.13 & 6.70 & 6.01 & 1.95 & 25.68 & 19.20 & 20.73 \\
\hline Rectangular & $8 \times 11$ & 88 & 6.11 & 4.11 & 4.34 & 2.40 & 9.47 & 6.79 & 5.82 & 2.97 & 22.50 & 15.74 & 18.75 \\
\hline Rectangular & $16 \times 11$ & 176 & 5.62 & 4.00 & 2.02 & 2.40 & 8.22 & 3.68 & 2.18 & 3.19 & 12.32 & 9.56 & 10.93 \\
\hline
\end{tabular}

PH6, plant height at six months; PH12, plant height at 12 months; PH18, plant height at 18 months; IHFF, insertion height of the first fruits; SD6, stem diameter at six months; SD12, stem diameter at 12 months; SD18, stem diameter at 18 months; PREC, precocity; NMF9, number of marketable fruit per plant at nine months; NMF14, number of marketable fruit per plant at 14 months; PROD, productivity; F, row; and P/F, plant per row.

Table 2. Estimates of coefficient of variation (CV), depending on the plot size in basic unit (Xbu), for the agronomic characteristics of Carica papaya fruit.

\begin{tabular}{lccccccccc}
\hline Form & Dimension & Xbu & \multicolumn{6}{c}{ Coefficient of variation (\%) } \\
\cline { 4 - 9 } & F x P/F & & FD & FL & FW & FF & PT & DIC & SS \\
\hline Plant & $1 \times 1$ & 1 & 6.63 & 6.15 & 17.14 & 19.87 & 11.53 & 9.38 \\
\hline Row & $2 \times 1$ & 2 & 4.88 & 4.37 & 12.40 & 14.14 & 8.93 & 6.73 \\
Row & $4 \times 1$ & 4 & 3.46 & 3.18 & 8.89 & 10.31 & 7.07 & 4.55 & 2.81 \\
Row & $8 \times 1$ & 8 & 2.67 & 2.60 & 6.99 & 7.85 & 5.31 & 3.16 & 1.98 \\
Row & $1 \times 11$ & 11 & 2.66 & 2.47 & 7.34 & 7.73 & 5.45 & 2.93 \\
Row & $16 \times 1$ & 16 & 2.40 & 2.03 & 5.37 & 5.45 & 4.21 & 2.68 & 1.12 \\
\hline Rectangular & $2 \times 11$ & 22 & 2.32 & 1.92 & 6.32 & 6.21 & 4.88 & 2.31 & 1.52 \\
Rectangular & $16 \times 2$ & 32 & 2.03 & 1.74 & 4.32 & 4.65 & 3.68 & 1.70 & 0.94 \\
Rectangular & $2 \times 22$ & 44 & 1.16 & 1.68 & 4.96 & 4.29 & 3.78 & 1.91 & 1.10 \\
Rectangular & $8 \times 11$ & 88 & 1.88 & 1.38 & 4.92 & 4.68 & 4.41 & 1.30 & 1.08 \\
Rectangular & $16 \times 11$ & 176 & 2.12 & 0.48 & 3.76 & 5.10 & 4.06 & 0.89 & 0.76 \\
\hline
\end{tabular}

FD, fruit diameter; FL, fruit length; FW, fruit weight; FF, fruit firmness; PT, pulp thickness; DIC, diameter of the inner cavity; SS, soluble solids; F, row; and $\mathrm{P} / \mathrm{F}$, plant per row. 
et al., 2008, 2018). In addition, there is a difference between the genetic materials and crop management applied, as well as to soil and climate conditions to which the studies were subjected (Boer et al., 2008).

Thedeterminationcoefficients formorphoagronomic characters of fruit quality ranged from $\mathrm{r}^{2}=0.6011$ to $\mathrm{r}^{2}=0.8864$ (Figure 1 and 2), which corresponds to the number of marketable fruit per plant at 14 months and plant height at 12 months, respectively.

It is worth noting that the variable number of marketable fruit per plant at 14 months showed a higher value of plot size (15.09 bu), for a lower value of determination coefficients (Table 3); however, this relationship is not direct in the determination of the size $\left(\mathrm{r}^{2}=0.7642\right.$ and $\left.\mathrm{X}_{0}=13.70 \mathrm{bu}\right)$ and precocity $\left(\mathrm{r}^{2}\right.$ $=0.7150$ and $\mathrm{X}_{0}=5.15 \mathrm{bu}$ ), and it is also necessary to

Table 3. Optimal plot size obtained with the linear model of plateau response for the agronomic characteristics of Carica papaya plants.

\begin{tabular}{|c|c|c|c|c|c|c|}
\hline \multirow[t]{2}{*}{ Variable } & \multirow[t]{2}{*}{ If } & \multicolumn{3}{|c|}{ Parameter } & \multirow[t]{2}{*}{$\mathrm{X}_{0}$} & \multirow[t]{2}{*}{$\approx \mathrm{Xbu}$} \\
\hline & & $\mathrm{CVi}$ & $\beta_{0}$ & $\beta_{1}$ & & \\
\hline \multirow{2}{*}{ PH6 } & $\mathrm{X} \leq \mathrm{X}_{0}$ & & 17.39 & -1.96 & \multirow{2}{*}{5.75} & \multirow{2}{*}{6} \\
\hline & $\mathrm{X}>\mathrm{X}_{0}$ & 6.12 & & & & \\
\hline \multirow{2}{*}{ PH12 } & $\mathrm{X} \leq \mathrm{X}_{0}$ & & 13.45 & -1.51 & \multirow{2}{*}{5.69} & \multirow{2}{*}{6} \\
\hline & $\mathrm{X}>\mathrm{X}_{0}$ & 4.86 & & & & \\
\hline \multirow{2}{*}{ PH18 } & $\mathrm{X} \leq \mathrm{X}_{0}$ & & 9.41 & -0.41 & \multirow{2}{*}{13.70} & \multirow{2}{*}{14} \\
\hline & $\mathrm{X}>\mathrm{X}_{0}$ & 3.79 & & & & \\
\hline \multirow{2}{*}{ SD6 } & $\mathrm{X} \leq \mathrm{X}_{0}$ & & 32.16 & -3.79 & \multirow{2}{*}{5.98} & \multirow{2}{*}{6} \\
\hline & $\mathrm{X}>\mathrm{X}_{0}$ & 9.54 & & & & \\
\hline \multirow{2}{*}{ SD12 } & $\mathrm{X} \leq \mathrm{X}_{0}$ & & 12.99 & -0.54 & \multirow{2}{*}{13.37} & \multirow{2}{*}{14} \\
\hline & $\mathrm{X}>\mathrm{X}_{0}$ & 5.75 & & & & \\
\hline \multirow{2}{*}{ SD18 } & $\mathrm{X} \leq \mathrm{X}_{0}$ & & 10.88 & -0.45 & \multirow{2}{*}{13.84} & \multirow{2}{*}{14} \\
\hline & $\mathrm{X}>\mathrm{X}_{0}$ & 4.70 & & & & \\
\hline \multirow{2}{*}{ PREC } & $\mathrm{X} \leq \mathrm{X}_{0}$ & & 12.13 & -1.72 & \multirow{2}{*}{5.15} & \multirow{2}{*}{6} \\
\hline & $\mathrm{X}>\mathrm{X}_{0}$ & 3.28 & & & & \\
\hline \multirow{2}{*}{ IHFF } & $\mathrm{X} \leq \mathrm{X}_{0}$ & & 16.49 & -2.18 & \multirow{2}{*}{5.67} & \multirow{2}{*}{6} \\
\hline & $\mathrm{X}>\mathrm{X}_{0}$ & 4.13 & & & & \\
\hline \multirow{2}{*}{ NMF9 } & $\mathrm{X} \leq \mathrm{X}_{0}$ & & 59.53 & -5.91 & \multirow{2}{*}{6.32} & \multirow{2}{*}{7} \\
\hline & $\mathrm{X}>\mathrm{X}_{0}$ & 22.12 & & & & \\
\hline \multirow{2}{*}{ NMF14 } & $\mathrm{X} \leq \mathrm{X}_{0}$ & & 33.78 & -1.20 & \multirow{2}{*}{15.09} & 16 \\
\hline & $\mathrm{X}>\mathrm{X}_{0}$ & 15.70 & & & & 10 \\
\hline PROD & $\mathrm{X} \leq \mathrm{X}_{0}$ & & 36.90 & -1.40 & 13.93 & 14 \\
\hline & $\mathrm{X}>\mathrm{X}_{0}$ & 17.36 & & & & \\
\hline
\end{tabular}

PH6, plant height at six months; PH12, plant height at 12 months; PH18, plant height at 18 months; SD6, stem diameter at six months; SD12, stem diameter at 12 months; SD18, stem diameter at 18 months; PREC, precocity; IHFF, insertion height of the first fruit; NMF9, number of marketable fruit per plant at nine months; NMF14, number of marketable fruit per plant at 14 months; PROD, productivity; X, plot size in basic unit (bu); $\beta_{0}$ and $\beta_{1}$, estimated parameters of the model; $X_{0}$, greatest plot size; $\mathrm{Xbu}$, greatest plot size rounded to the nearest whole number. compare the plot sizes for plant height characters at 18 months, stem diameter at 18 months $\left(\mathrm{r}^{2}=0.8158\right.$ and $\mathrm{X}_{0}$ $=13.84 \mathrm{bu}$ ), and number of marketable fruit per plan at the ninth month $\left(\mathrm{r}^{2}=0.8120\right.$ and $\left.\mathrm{X}_{0}=6.32 \mathrm{bu}\right)$, despite the coefficient values of determination often close that of the plot size are different. According to Oliveira et al. (2011), the linear model of plateau response do not fit as well, since it is two straight segments to explain an exponential trend, so in this method considered the most important the point of intercession of the two straight lines, which indicates the optimum between the experimental plot size and the precision gain.

From these results, the largest plot size $-15.70 \mathrm{bu}$ ( $\sim 16 \mathrm{bu}$ ), corresponding to $96 \mathrm{~m}^{2}$ - should be considered for use as the optimal plot size. However, the overall mean of the evaluated characters, as adopted by Peixoto et al. (2011) and Sousa et al. (2015), in this case of $7.90 \mathrm{bu}$ ( $\sim 8 \mathrm{bu}$ ) corresponding to $48 \mathrm{~m}^{2}$.

It is important to note that the estimated plot sizes should not be observed as the maximum size of the plot, but as the minimum ones to be used, since, if there are necessary resources, it is up to the researcher to adopt any plot size above the minimum value (Peixoto et al., 2011). Therefore, it is possible to use the largest parcel size found, that is, approximately $16 \mathrm{bu}$.

Table 4. Optimal plot size determined by the linear model of plateau response for the agronomic characteristics related to the quality of Carica papaya fruit.

\begin{tabular}{|c|c|c|c|c|c|c|}
\hline \multirow[t]{2}{*}{ Variable } & \multirow[t]{2}{*}{ If } & \multicolumn{3}{|c|}{ Parameters } & \multirow[t]{2}{*}{$\mathrm{X}_{0}$} & \multirow[t]{2}{*}{$\approx \mathrm{Xbu}$} \\
\hline & & $\mathrm{CVi}$ & $\beta_{0}$ & $\beta_{1}$ & & \\
\hline \multirow{2}{*}{ FD } & $\mathrm{X} \leq \mathrm{X}_{0}$ & & 7.34 & -1.01 & \multirow{2}{*}{5.15} & \multirow{2}{*}{6} \\
\hline & $\mathrm{X}>\mathrm{X}_{0}$ & 2.16 & & & & \\
\hline \multirow{2}{*}{$\mathrm{FL}$} & $\mathrm{X} \leq \mathrm{X}_{0}$ & & 6.75 & -0.93 & \multirow{2}{*}{5.31} & \multirow{2}{*}{6} \\
\hline & $X>X_{0}$ & 1.79 & & & & \\
\hline \multirow{2}{*}{ FW } & $\mathrm{X} \leq \mathrm{X}_{0}$ & & 18.89 & -2.61 & \multirow{2}{*}{5.14} & \multirow{2}{*}{6} \\
\hline & $\mathrm{X}>\mathrm{X}_{0}$ & 5.50 & & & & \\
\hline \multirow{2}{*}{ FF } & $\mathrm{X} \leq \mathrm{X}_{0}$ & & 21.78 & -3.00 & \multirow{2}{*}{5.34} & \multirow{2}{*}{6} \\
\hline & $\mathrm{X}>\mathrm{X}_{0}$ & 5.75 & & & & \\
\hline \multirow{2}{*}{ PT } & $\mathrm{X} \leq \mathrm{X}_{0}$ & & 12.47 & -1.41 & \multirow{2}{*}{5.67} & \multirow{2}{*}{6} \\
\hline & $\mathrm{X}>\mathrm{X}_{0}$ & 4.47 & & & & \\
\hline \multirow{2}{*}{ DCI } & $\mathrm{X} \leq \mathrm{X}_{0}$ & & 10.47 & -1.54 & \multirow{2}{*}{5.44} & \multirow{2}{*}{6} \\
\hline & $X>X_{0}$ & 2.11 & & & & \\
\hline \multirow{2}{*}{ SS } & $\mathrm{X} \leq \mathrm{X}_{0}$ & & 6.09 & -0.85 & \multirow{2}{*}{5.58} & \multirow{2}{*}{6} \\
\hline & $\mathrm{X}>\mathrm{X}_{0}$ & 1.34 & & & & \\
\hline
\end{tabular}

FD, fruit diameter; FL, fruit length; FW, fruit weight; FF, fruit firmness; PT, pulp thickness; DIC, diameter of the inner cavity; SS, soluble solids; $\mathrm{X}$, plot size in basic unit (bu); $\beta_{0}$ and $\beta_{1}$, estimated parameters of the model; $\mathrm{X}_{0}$, greatest plot size; $\mathrm{Xbu}$, greatest plot size rounded to the nearest whole number. 

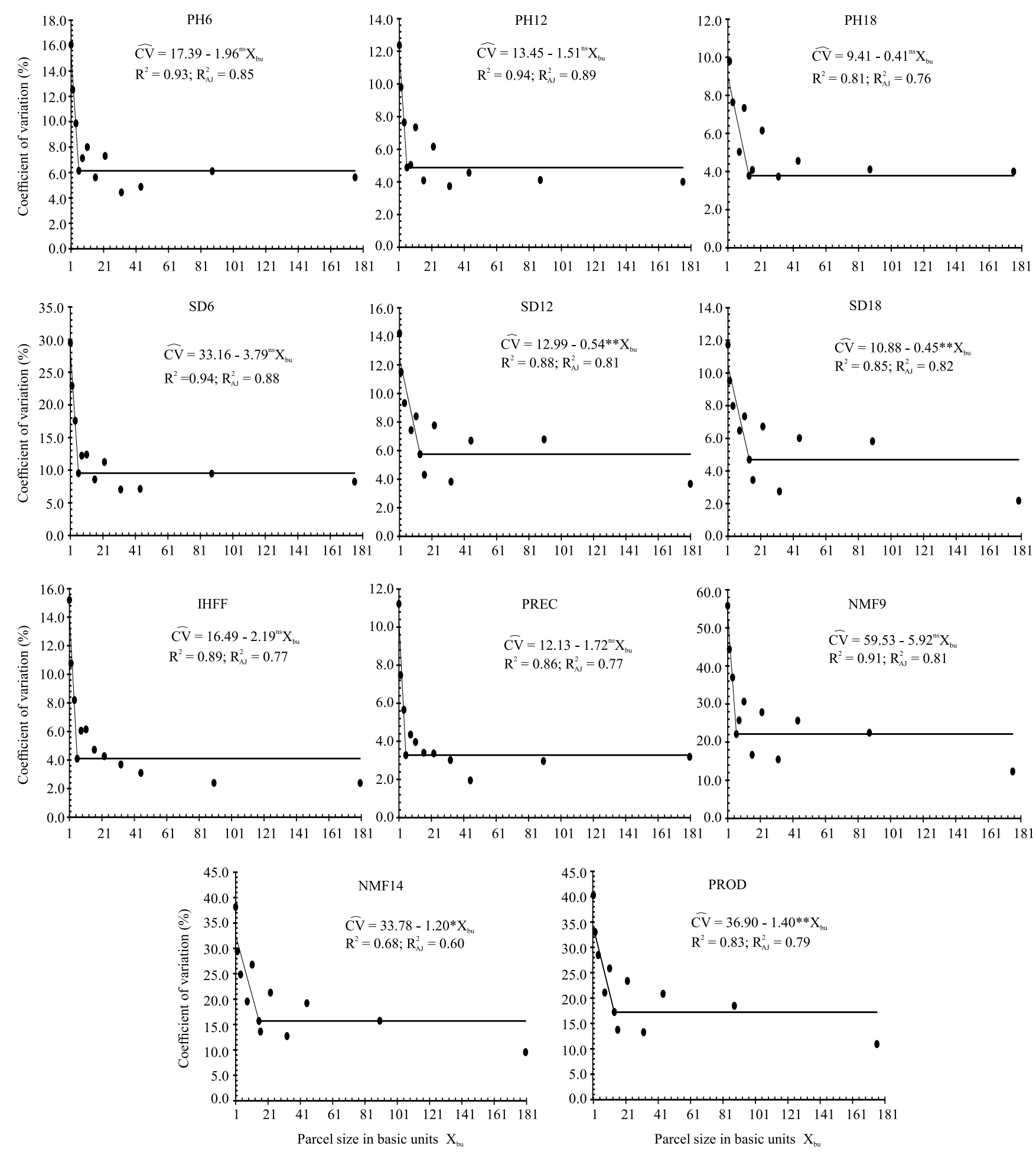

Figure 1. Relationship between the coefficient of variation (CV) and the greatest plot size (Xbu) in basic unit (bu), using the linear model of plateau response for the following variables of agronomic characteristics of Carica papaya plants: PH6, plant height at six months; PH12, plant height at 12 months; PH18, plant height at 18 months; SD6, stem diameter at six months; SD12, stem diameter at 12 months; SD18, stem diameter at 18 months; IHFF, insertion height of the first fruit; PREC, precocity; NMF9, number of marketable fruit per plant at nine months; NMF14, number of marketable fruit per plant at 14 months; and PROD, productivity. 

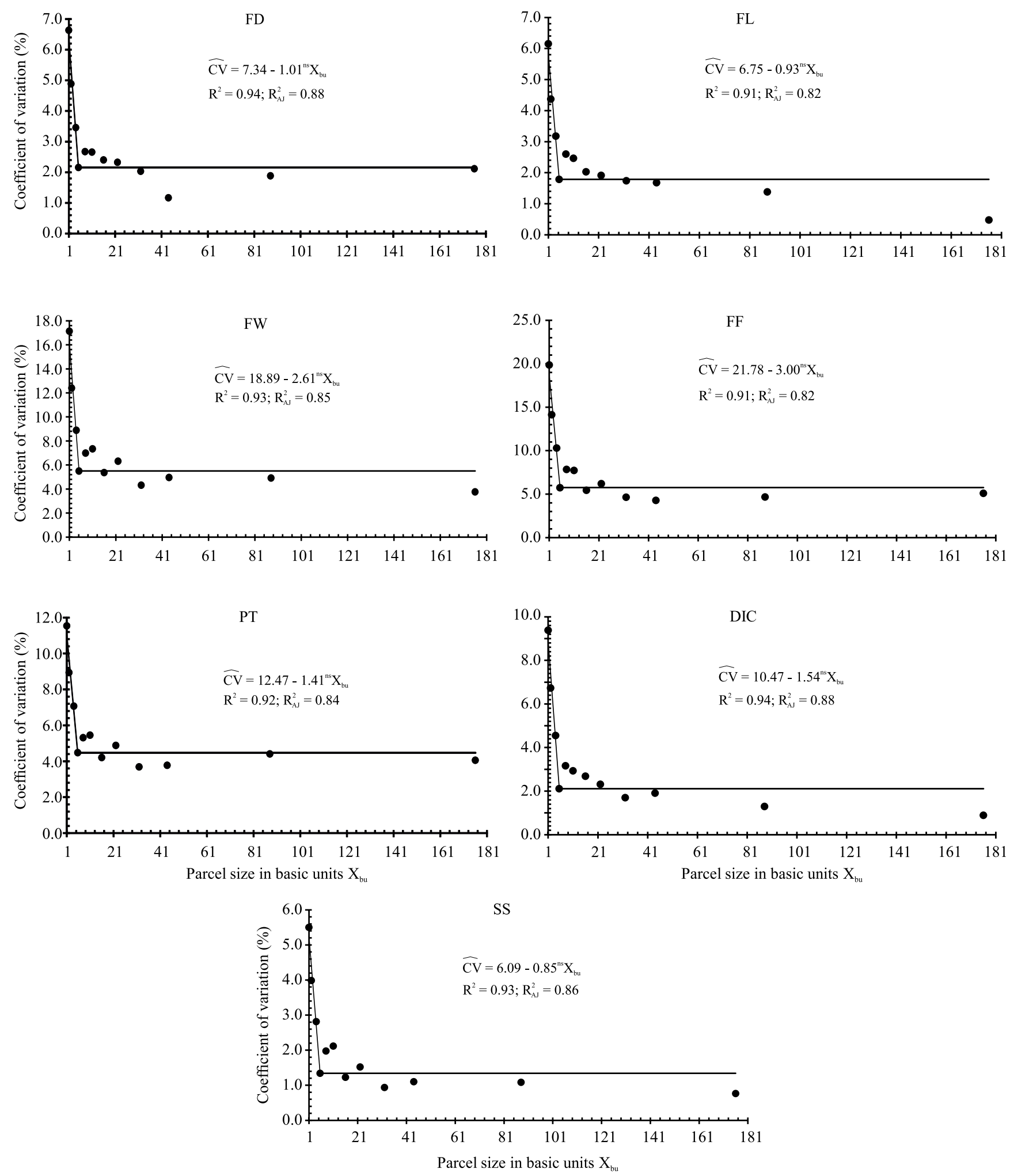

Figure 2. Relationship between the coefficient of variation (CV) and the greatest plot size (Xbu) in basic unit (bu), using the linear model of plateau response for the following variables of agronomic characteristics related to the fruit quality of Carica papaya: FD, fruit diameter; FL, fruit length; FW, fruit weight; FF, fruit firmness; PT, pulp thickness; DIC, diameter of the inner cavity; and SS, soluble solids. 


\section{Conclusions}

1. The experimental plot sizes for papaya plants, estimated using the LMPR model, vary with the evaluated characteristics.

2. In the soil and climatic conditions of the Recôncavo Baiano, the optimal experimental plot size for papaya cultivation is eight plants for $48 \mathrm{~m}^{2}$ area, using $3 \mathrm{~m}$ spacing between rows and $2 \mathrm{~m}$ between plants.

\section{Acknowledgments}

To Conselho Nacional de Desenvolvimento Científico e Tecnológico (CNPq), for the Grant no. 2015/154291-5 to the first author; and to Embrapa Mandioca e Fruticultura, for supporting this research.

\section{References}

ANUÁRIO BRASILEIRO DA FRUTICULTURA 2018. Santa Cruz do Sul: Gazeta Santa Cruz, 2018. 49p.

BOER, C.A.; ASSIS, R.L. de; SILVA, G.P.; BRAZ, A.J.B.P.; BARROSO, A.L. de L.; CARGNELUTTI FILHO, A.; PIRES, F.R. Biomassa, decomposição e cobertura do solo ocasionada por resíduos culturais de três espécies vegetais na região centro-oeste do Brasil. Revista Brasileira de Ciência do Solo, v.32, p.843-851, 2008. DOI: https://doi.org/10.1590/S0100-06832008000200038.

CARGNELUTTI FILHO, A.; ALVES, B.M.; BURIN, C.; KLEINPAUL, J.A.; NEU, I.M.M.; SILVEIRA, D.L.; SIMÕES, F.M.; SPANHOLI, R.; MEDEIROS, L.B. Tamanho de parcela e número de repetições em ervilha forrageira. Ciência Rural, v.45, p.1174-1182, 2015. DOI: https://doi.org/10.1590/0103$8478 \mathrm{cr} 20141043$.

CARGNELUTTI FILHO, A.; TOEBE, M.; BURIN, C.; CASAROTTO, G.; LÚCIO, A.D.C. Métodos de estimativa do tamanho ótimo de parcelas experimentais de híbridos de milho simples, triplo e duplo. Ciência Rural, v.41, p.1509-1516, 2011. DOI: https://doi.org/10.1590/S0103-84782011000900004.

DANTAS, J.L.L.; LUCENA, R.S.; VILAS BOAS, S.A. Avaliação agronômica de linhagens e híbridos de mamoeiro. Revista Brasileira de Fruticultura, v.37, p.138-148, 2015. DOI: https://doi.org/10.1590/0100-2945-022/14.

DONATO, S.L.R.; SILVA, J.A. da; GUIMARÃES, B.V.C.; SILVA, S. de O. e. Experimental planning for the evaluation of phenotipic descriptors in banana. Revista Brasileira de Fruticultura, v.40, e-962, 2018. DOI: https://doi.org/10.1590/0100-29452018962.

DONATO, S.L.R.; SIQUEIRA, D.L. de; SILVA, S. de O. E; CECON, P.R.; SILVA, J.A. da; SALOMÃO, L.C.C. Estimativas de tamanho de parcelas para avaliação de descritores fenotípicos em bananeira. Pesquisa Agropecuária Brasileira, v.43, p.957-969, 2008. DOI: https://doi.org/10.1590/S0100-204X2008000800003.
EMBRAPA. Serviço Nacional de Levantamento e Conservação de Solos. Levantamento detalhado dos solos do Centro Nacional de Pesquisa de Mandioca e Fruticultura Tropical. Cruz das Almas: Embrapa-CNPMF, 1993. 126p. (Embrapa-CNPMF. Boletim de pesquisa, 7).

IBGE. Instituto Brasileiro de Geografia e Estatística. Produção Agrícola Municipal. 2017. Available: <https://www.ibge.gov.br/ estatisticas/economicas/agricultura-e-pecuaria/9117-producaoagricola-municipal-culturas-temporarias-e-permanentes. html? $=\& \mathrm{t}=$ resultados $>$. Accessed on: May 292018.

LEONARDO, F. de A.P.; PEREIRA, W.E.; SILVA, S. de M.; ARAÚJO, R. da C.; MENDONÇA, R.M.N. Tamanho ótimo da parcela experimental de abacaxizeiro 'Vitória'. Revista Brasileira de Fruticultura, v.36, p.909-916, 2014. DOI: https://oi.org/10.1590/0100-2945-396/13.

LUZ, L.N. da; PEREIRA, M.G.; BARROS, F.R.; BARROS, G. de B.; FERREGUETTI, G.A. Novos híbridos de mamoeiro avaliados nas condições de cultivo tradicional e no Semiárido brasileiro. Revista Brasileira de Fruticultura, v.37, p.159-171, 2015. DOI: https://doi.org/10.1590/0100-2945-069/14.

OLIVEIRA, A.M.G.; COELHO, E.F. Calagem e adubação para mamoeiro. In.: BORGES, A.L.; SOUZA, L. da S. (Ed.). Recomendações de calagem e adubação para abacaxi, acerola, banana, laranja, tangerina, lima ácida, mamão, mandioca, manga e maracujá. Cruz das Almas: Embrapa Mandioca e Fruticultura, 2009. p.108-125.

OLIVEIRA, E.J. de; LIMA, D.S. de; LUCENA, R.S.; MOTTA, T.B.N.; DANTAS, J.L.L. Correlações genéticas e análise de trilha para número de frutos comerciais por planta em mamoeiro. Pesquisa Agropecuária Brasileira, v.45, p.855-862, 2010. DOI: https://doi.org/10.1590/S0100-204X2010000800011.

OLIVEIRA, G.M.V.; MELLO, J.M. de; LIMA, R.R. de; SCOLFORO, J.R.S.; OLIVEIRA, A.D. de. Tamanho e forma de parcelas experimentais para Eremanthus erythropappus. Cerne, v.17, p.327-338, 2011. DOI: https://doi.org/10.1590/S010477602011000300006 .

PARANAIBA, P.F.; FERREIRA, D.F.; MORAIS, A.R. de. Tamanho ótimo de parcelas experimentais: proposição de métodos de estimação. Revista Brasileira de Biometria, v.27, p.255-268, 2009.

PEIXOTO, A.P.B.; FARIA, G.A.; MORAIS, A.R. de. Modelos de regressão com platô na estimativa do tamanho de parcelas em experimento de conservação in vitro de maracujazeiro. Ciência Rural, v.41, p.1907-1913, 2011. DOI: https://doi.org/10.1590/ S0103-84782011001100010.

RIBEIRO JÚNIOR, J.I. Análises estatísticas no SAEG. Viçosa: UFV, 2001. 301p.

SANTOS, G.O. dos; CARGNELUTTI FILHO, A.; ALVES, B.M.; BURIN, C.; FACCO, G.; TOEBE, M.; KLEINPAUL, J.A.; NEU, I.M.M.; STEFANELLO, R.B. Tamanho de parcela e número de repetições em feijão guandu. Ciência Rural, v.46, p.44-52, 2016. DOI: https://doi.org/10.1590/0103-8478cr20150124.

SCHMILDT, E.R.; SCHMILDT, O.; CRUZ, C.D.; CATTANEO, L.F.; FERREGUETTI, G.A. Optimum plot size and number of replications in papaya field experiment. Revista Brasileira de

Pesq. agropec. bras., Brasília, v.54, e00768, 2019

DOI: 10.1590/S1678-3921.pab2019.v54.00768 
Fruticultura,v.38, e-373, 2016. DOI: https://doi.org/10.1590/010029452016373.

SILVA, L.F. de O. da; CAMPOS, K.A.; MORAIS, A.R. de; COGO, F.D.; ZAMBON, C.R. Tamanho ótimo de parcela para experimentos com rabanetes. Revista Ceres, v.59, p.624-629, 2012. DOI: https://doi.org/10.1590/S0034-737X2012000500007.
SOUSA, R.P. de; SILVA, P.S.L. e; ASSIS, J.P. de; SILVA, J. da; OLIVEIRA, V.R. de; OLIVEIRA, A.M. de P. Tamanho ótimo de parcela para avaliação do rendimento de grãos do girassol. Revista Brasileira de Engenharia Agrícola e Ambiental, v.19, p.21-26, 2015. DOI: https://doi.org/10.1590/1807-1929/agriambi. v19n1p21-26. 